\title{
Effect of glucose supply on fasting nitrogen excretion and effect of level and type of volatile fatty acid infusion on response to protein infusion in cattle
}

\author{
E. R. Ørskov*, D. E. Meehan, N. A. MacLeod and D. J. Kyle \\ Rowett Research Institute, Bucksburn, Aberdeen AB21 9SB, UK \\ (Received 10 February 1998 - Revised 3 September 1998 - Accepted 19 November 1998)
}

\begin{abstract}
Two experiments were carried out on cattle nourished entirely by intragastric infusion, to determine the extent to which glucose or a glucose precursor determines the response to protein infusion in energy-undernourished animals. In order to determine the requirement for glucose in 1-year-old fasting cattle, glucose was infused at increments to supply $0,1 \cdot 5,2 \cdot 5,3 \cdot 5,4 \cdot 5,5 \cdot 5$ and $6.5 \mathrm{~g} / \mathrm{kg}$ metabolic body weight $\left(\mathrm{W}^{0.75}\right)$ and the effects on plasma $\beta$-hydroxybutyrate and $\mathrm{N}$ excretion were measured. At $5.5 \mathrm{~g}$ glucose $/ \mathrm{kg} \mathrm{W}^{0.75}$ plasma $\beta$-hydroxybutyrate was reduced to a basal level of $1.65 \mathrm{mmol} / \mathrm{l}$ and fasting $\mathrm{N}$ excretion reduced from 529 to $280 \mathrm{mg} \mathrm{N} / \mathrm{kg} \mathrm{W}^{0.75}$. No further reduction was observed with the higher level of $6.5 \mathrm{~g}$ glucose $/ \mathrm{kg} \mathrm{W}^{0.75}$. In the second trial, three steers were used in a $3 \times 3$ Latin square design and infused with a volatile fatty acid mixture of 65,27 and $8 \mathrm{~mol}$ acetic, propionic and butyric acids respectively/100 mol, either at an estimated maintenance energy level of $450 \mathrm{~kJ} / \mathrm{kg} \mathrm{W}^{0.75}$ and supplying a calculated glucose equivalent level of $13.0 \mathrm{~g} / \mathrm{kg} \mathrm{W}^{0.75}(\mathrm{M} 1 \mathrm{~A})$, or at $1.5 \times$ maintenance supplying a glucose equivalent of $20 \mathrm{~g} / \mathrm{kg} \mathrm{W}^{0.75}$ (M1.5A). Another mixture infused at the maintenance energy level contained 49, 43 and 8 mol acetic, propionic and butyric acids respectively/100 mol but with a glucose equivalent of $20 \mathrm{~g} /$ $\mathrm{kg} \mathrm{W}^{0.75}(\mathrm{M} 1 \mathrm{P})$. Casein was infused at each of these energy treatments to supply $0,200,400,800$, 1600 and $2500 \mathrm{mg} \mathrm{N} / \mathrm{kg} \mathrm{W}^{0.75}$ daily, and $\mathrm{N}$ balance and blood metabolites were measured. $\mathrm{N}$ retention increased linearly ( $r$ 0.98) with casein infusion. The coefficients for $\mathrm{N}$ retention were $0.55,0.57$ and 0.64 for M1A, M1.5A and M1P respectively. The mean efficiency of N utilization was 0.58 . The results suggest that provided the glucose need is met there is no relationship between energy supply and efficiency and level of protein retention. However, the results also indicate that glucose requirement in cattle may be higher than that previously observed in sheep.
\end{abstract}

Glucose requirement: Intragastric nutrition: Nitrogen excretion: Volatile fatty acids: Protein retention

Work in this laboratory using intragastric nutrition in ruminants (Ørskov et al. 1979) has challenged the concept that protein requirement is dependent on energy supply (Balch, 1967). According to this concept animals fed below their maintenance energy requirement would not attain positive retention. However, later work (Ørskov et al. 1983) showed that fasted sheep responded to protein, and were in positive protein balance while in substantial negative energy balance. This concept was further elaborated by Fattet et al. (1984), showing that lambs in substantial negative energy balance on straw diets increased their carcass weight when a protected protein source was given. Evidently protein deposition was fuelled by oxidation of body fat.

In more recent work Chowdhury et al. (1997a) compared responses in fasted sheep with those of sheep given a mixture of volatile fatty acids (VFA) to supply $250 \mathrm{~kJ} / \mathrm{kg}$ metabolic body weight $\left(\mathrm{W}^{0.75}\right)$. They observed that at zero protein intake there were substantial differences in $\mathrm{N}$ loss, depending on whether energy was given or not. However, when casein was also infused it did not influence $\mathrm{N}$ retention, as the casein apparently provided some glucose precursors so that no effect of energy was apparent. It was postulated that the effect of energy supply was due to supply of glucose precursors, since $\beta$-hydroxybutyrate (BHB) was elevated in the fasted sheep. Subsequently, Chowdhury et al. (1997b) showed that by supplying a VFA mixture high in propionic acid at $91 \mathrm{~kJ} / \mathrm{kg} \mathrm{W}^{0.75}$ the fasting $\mathrm{N}$ excretion and plasma BHB were in the normal basal range and energy supply had no effect on $\mathrm{N}$ retention. While this work was done with sheep, some preliminary work reported by Liu et al. (1997) on cattle maintained by intragastric infusion indicated that energy level influenced responses to protein, but there were also indications that the glucose requirement 
in cattle was higher than that in sheep, and that these results were perhaps influenced by the supply of a glucose precursor. The work reported here tests the hypothesis that when the glucose requirement of cattle is met there will be little or no response in protein retention to different levels of energy and glucose supply. In the first experiment the level of glucose infusion needed to reduce plasma BHB and urinary $\mathrm{N}$ excretion to basal levels was determined. A higher level of glucose was then supplied at each of two different VFA mixtures to supply estimated maintenance and $1.5 \times$ maintenance energy requirement.

\section{Materials and methods}

\section{Animals}

Five steers (Limosine $\times$ Friesian), each about 12 months old with an average body weight of $340 \mathrm{~kg}$, were used in the infusion trial. Each animal was fitted with a rumen cannula and abomasal catheter as described by MacLeod et al. (1982). They were housed in individual pens and offered a mixed hay-concentrate diet for 5 weeks before and after surgery. They were then transferred to open-circuit respiration hoods where normal diets were discontinued and nutrients supplied by intragastric infusion (Ku Vera et al. 1990). Nutrient intakes were then stepped up from a basal level of 0.25 maintenance to reach maintenance level (defined as $450 \mathrm{~kJ} / \mathrm{kg} \mathrm{W}^{0.75}$; Ørskov et al. 1979a) over a period of $10 \mathrm{~d}$. Individual weights were recorded at the start of the trial and converted to their corresponding $\mathrm{W}^{0.75}$, from which calculated levels of infusates were determined.

\section{Expt 1. Treatments and design}

Two steers were infused with maintenance levels of VFA and casein-N (defined as $450 \mathrm{~kJ} / \mathrm{kg} \mathrm{W}^{0.75}$ and $400 \mathrm{mg} \mathrm{N} /$ $\mathrm{kg} \mathrm{W}^{0.75}$ daily; Ørskov \& McLeod, 1982) for four consecutive days. This treatment was then followed by a full $2 \mathrm{~d}$ fast before six consecutive daily infusion periods of glucose at $1.5,2.5,3.5,4.5,5.5$ and $6.5 \mathrm{~g} / \mathrm{kg} \mathrm{W}^{0.75}$ respectively. The trace minerals and vitamins required according to MacLeod et al. (1982) were given at all times. The infusions were terminated when plasma BHB stabilized.

\section{Expt 2. Treatments and design}

This experiment was arranged as a $3 \times 3$ Latin square using three animals allocated to each of three VFA energy treatments in three periods. These treatments consisted of two at estimated maintenance, one high-propionic acid with 49, 43 and $8 \mathrm{~mol}$ acetic, propionic and butyric acids respectively/ $100 \mathrm{~mol}$ and one low-propionic acid with 65,27 and $8 \mathrm{~mol}$ acetic, propionic and butyric acids respectively/100 mol. The third treatment was infusion at $1.5 \times$ estimated maintenance requirement, such that the amount of glucogenic precursor supplied by propionic acid was similar to that supplied by the high-propionic acid mixture infused at maintenance energy requirement. The calculated yields of glucose derived from propionic acid between the different mixtures were 13 and $20 \mathrm{~g} / \mathrm{kg} \mathrm{W}^{0.75}$. It is assumed here that $2 \mathrm{~mol}$ propionic acid is equal to $1 \mathrm{~mol}$ glucose, although it is known that not all propionic acid absorbed reaches the liver in the form of propionic acid (Weekes, 1989). These glucose yields were in excess of the glucose infusion required to reduce BHB to basal levels, in order to establish whether additional levels of glucose caused any further reduction. Six different levels of casein (i.e. 0, 200, 400, 800, 1600 and $2500 \mathrm{mg} \mathrm{N} / \mathrm{kg} \mathrm{W}^{0.75}$ ), each given for 3-4 duration, were then infused with each of the energy levels within the Latin square design. In each case values from the first day at each casein level were deleted when calculating respective $\mathrm{N}$ balances. Hovell et al. (1983) earlier showed that the responses to small changes in the infusion of energy and protein were rapid, and that the values even on the first day of each treatment were typical of true responses. However, we chose to omit the first day to avoid any possibility of a carry-over effect. It would have been desirable to have randomized the levels of casein. However, this would result in large changes between infusion levels and would increase the length of the experiment; since the main question was about differences due to type and level of VFA infusion, the method chosen was considered to be the best.

\section{Housing and management}

The animals were housed consecutively in each of two open-circuit respiration hoods so that energy balance could be determined. The hoods were constructed on conventional concrete metabolic stalls as described by Ku Vera et al. (1990). These provided rubber-mat flooring with an inset metal grid, from which urine passed via a plastic tray to a plastic container underneath. Faeces were collected on a separate fibreglass tray to the rear of the animal, but because no food was given amounts were small and therefore bulked over each of the energy treatments. During the experimental period the chambers were opened daily to facilitate administration of vitamins and trace minerals to the abomasum and removal of rumen samples by syringe. Blood samples were taken on the last day of each treatment. Gases were continually exhausted from the respiration hood.

\section{Collection and analysis of urine}

Urine collections were made for each $24 \mathrm{~h}$ period and collected in $\mathrm{H}_{2} \mathrm{SO}_{4}$ to ensure a final $\mathrm{pH}$ of less than $3 \cdot 8$. Sub-samples of approximately $100 \mathrm{ml}$ were taken for analysis and stored at $1^{\circ}$. Total $\mathrm{N}$ was determined using the automated Kjeldahl method (Davidson et al. 1970) and urea using the technique of Technicon Instrument Co. as modified by Marsh et al. (1965).

\section{Analysis of blood samples}

Blood samples (approximately $20 \mathrm{ml}$ ) were withdrawn by jugular venepuncture into evacuated tubes containing EDTA. They were centrifuged for $10 \mathrm{~min}$ at $1235 \mathrm{~g}$ and the plasma was stored at $-70^{\circ}$. BHB was determined by the technique of Zavin \& Snarr (1973), glucose by the method of Trinder (1969), free fatty acids using the technique of Matsubara et al. (1983) and urea by the method of Marsh et al. (1965). 


\section{Rumen samples}

Rumen samples were obtained twice daily at 09.00 and 18.00 hours through the rumen cannula using vinyl tubing connecting to a $60 \mathrm{ml}$ syringe. Both $\mathrm{pH}$ and osmolality were determined immediately with the objective of keeping values between $6 \cdot 2$ and $6 \cdot 8$, and 300 and $340 \mathrm{mosmol} / \mathrm{l}$ respectively. In all cases the total volume of infusion was kept at approximately 1.0 litre $/ \mathrm{kg} \mathrm{W}^{0.75}$.

\section{Results}

Expt 1. Nitrogen excretion and plasma $\beta$-hydroxybutyrate

Table 1 shows the responses in urinary $\mathrm{N}$ excretion and plasma BHB to fasting plus incremental glucose infusions for the two steers. N excretion decreased from a fasting level

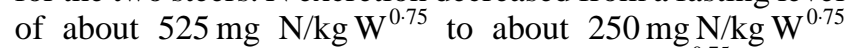
at a daily glucose infusion level of $5 \cdot 5 \mathrm{~g} / \mathrm{kg} \mathrm{W}^{0.75}$. Above this level of glucose infusion $\mathrm{N}$ excretion showed no further reduction. At fasting the plasma $\mathrm{BHB}$ was about $4 \mathrm{mmol} / \mathrm{l}$, but fell to $1.65 \mathrm{mmol} / \mathrm{l}$ at a glucose infusion of $5.5 \mathrm{~g} / \mathrm{kg} \mathrm{W}^{0.75}$. With glucose infusion above $5 \cdot 5 \mathrm{~g} / \mathrm{kg} \mathrm{W}^{0.75}$ no further reduction in BHB was apparent. These results demonstrate a $\mathrm{N}$ sparing effect of glucose on protein catabolism but also suggest a limit to this effect, with no additive effect beyond an infusion level of $5 \cdot 5 \mathrm{~g}$ glucose $/ \mathrm{kg} \mathrm{W}^{0.75}$ daily.

It was apparent that $\mathrm{N}$ excretion and $\mathrm{BHB}$ were correlated. $\mathrm{BHB}(Y ; \mathrm{mmol} / \mathrm{l})$ could be predicted from the equation $Y=0.003 X+1 \cdot 13$, where $X$ is $\mathrm{N}$ excretion $\left(\mathrm{mg} / \mathrm{kg} \mathrm{W}^{0.75} ; r\right.$ 0.78).

\section{Expt 2. Nitrogen excretion and plasma $\beta$-hydroxybutyrate}

Fig. 1 shows the $\mathrm{N}$ balance for the two treatments at estimated energy maintenance to supply 13 or $20 \mathrm{~g}$ glucose equivalent, or the $1.5 \times$ maintenance energy level also supplying $20 \mathrm{~g}$ glucose equivalent. There was no consistent difference in the response to casein infusions, although the coefficient of $\mathrm{N}$ retention for $20 \mathrm{~g}$ glucose equivalent at maintenance (0.64) was significantly higher than that for the other treatment $(P<0 \cdot 05)$. The regression equations describing the response in $\mathrm{N}$ balance $\left(Y ; \mathrm{mg} \mathrm{N} / \mathrm{kg} \mathrm{W}^{0.75}\right.$ per $\mathrm{d})$ to casein infusion $(X$; mg casein-N/d) were as follows:

maintenance, low-propionic acid infusion:

$Y=-254+0.55(\operatorname{se} 0.0133) X(r 0.98, P<0.01, n 18)$, maintenance, high-propionic acid infusion:

$Y=-283+0.64(\operatorname{se} 0.00055) X(r 0.99, P<0.01, n 18)$,

$1.5 \times$ maintenance, low-propionic acid infusion:

$Y=-227+0.57(\operatorname{SE} 0 \cdot 00029) X(r 0.99, P<0.01, n 18)$.

There was little difference in plasma BHB concentration between each of the energy treatments. The overall mean value was 1.77 (range $1.45-2.3$ ) $\mathrm{mmol} / \mathrm{l}$.

There was no significant difference $(P>0.05)$ in plasma glucose levels, which ranged between 4.2 and $4.7 \mathrm{mmol} / \mathrm{l}$.

Plasma urea concentration increased linearly with casein infusion from 0.8 to $5.8 \mathrm{mmol} / \mathrm{l}$, and there was no significant treatment difference $(P>0 \cdot 05)$.

\section{Expt 2. Energy metabolism in response to treatment}

Fig. 2 shows the effect of changes in level and molar proportion of VFA infused on estimated heat production. There was no significant difference in heat production between the two maintenance-energy infusion levels, but as expected heat production was greater at the higher energy supply. The average heat production increased from 464 to $544 \mathrm{~kJ} / \mathrm{kg} \mathrm{W}^{0.75}$ i.e. an efficiency of energy retention of $0 \cdot 64$.

\section{Discussion}

\section{Glucose requirements}

Glucose requirement was determined indirectly in fasting cattle as the amount of infused glucose required to reduce plasma BHB to basal levels of approximately $1.5 \mathrm{mmol} / \mathrm{l}$ (Ørskov \& MacLeod, 1993). The relationship between plasma BHB and corresponding $\mathrm{N}$ excretion levels shows that the process of fasting is characterized by a glucose deficiency involving elevated $\mathrm{N}$ excretion and plasma $\mathrm{BHB}$ concentration. Glucose requirement determined from Expt 1 was approximately $5.5 \mathrm{~g} / \mathrm{kg} \mathrm{W}^{0.75}$ daily. The second experiment, in which two VFA mixtures were infused at different energy levels supplying glucose precursor in excess of $5 \cdot 5 \mathrm{~g} / \mathrm{kg} \mathrm{W}^{0 \cdot 75}$, showed little effect of energy level on $\mathrm{N}$ balance (Fig. 1); in fact the highest coefficient of $\mathrm{N}$ retention was observed when $20 \mathrm{~g}$ glucose equivalent was given at the maintenance energy level.

Previous work by Liu et al. (1997) showed that when cattle were infused with VFA providing 300 and $600 \mathrm{~kJ} / \mathrm{kg} \mathrm{W}^{0.75}$

Table 1. Effect of abomasal glucose infusion in otherwise fasted steers on plasma $\beta$-hydroxybutyrate (BHB) and daily nitrogen excretion in the urine* $^{*}$

\begin{tabular}{|c|c|c|c|c|c|c|c|c|}
\hline & Steer no. & \multicolumn{7}{|c|}{ Glucose infusion $\left(\mathrm{g} / \mathrm{kg} \mathrm{W}^{0.75}\right)$} \\
\hline $\mathrm{BHB}(\mathrm{mmol} / \mathrm{l})$ & $\begin{array}{l}1 \\
2\end{array}$ & $\begin{array}{l}4 \cdot 1 \\
4.2\end{array}$ & $\begin{array}{l}3.0 \\
2.9\end{array}$ & $\begin{array}{l}2.4 \\
2.0\end{array}$ & $\begin{array}{l}2.2 \\
1.9\end{array}$ & $\begin{array}{l}2.1 \\
1.9\end{array}$ & $\begin{array}{l}1.8 \\
1.5\end{array}$ & $\begin{array}{l}1.8 \\
1.5\end{array}$ \\
\hline $\begin{array}{l}\text { N excretion } \\
\quad\left(\mathrm{mmol}^{\prime} / \mathrm{kg} \mathrm{W}^{0.75}\right)\end{array}$ & $\begin{array}{l}1 \\
2\end{array}$ & $\begin{array}{l}507 \\
550\end{array}$ & $\begin{array}{l}467 \\
520\end{array}$ & $\begin{array}{l}356 \\
371\end{array}$ & $\begin{array}{l}347 \\
312\end{array}$ & $\begin{array}{l}343 \\
260\end{array}$ & $\begin{array}{l}305 \\
217\end{array}$ & $\begin{array}{l}309 \\
227\end{array}$ \\
\hline
\end{tabular}

$\mathrm{W}^{0.75}$, metabolic body weight.

${ }^{*}$ For details of animals and procedures, see pp. 390-391. 


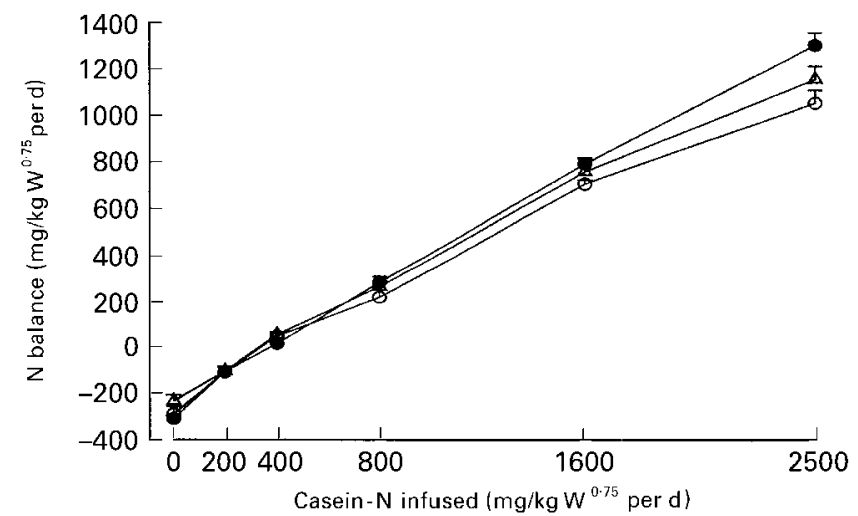

Fig. 1. Expt 2. Effect of infusion of different energy levels and types of volatile fatty acid in steers on responses in nitrogen retention to incremental casein infusion $(0,200,400,800,1600$ and 2500 $\mathrm{mg} / \mathrm{kg}$ metabolic body weight $\left.\left(\mathrm{W}^{0.75}\right)\right)$. (O), Maintenance $\left(450 \mathrm{~kJ} / \mathrm{kg} \mathrm{W}^{0.75}\right.$; Ørskov et al. 1977) on a low-propionic acid mixture $(65,27$ and $8 \mathrm{~mol}$ acetic, propionic and butyric acids respectively/100 mol); (๑), maintenance on a high-propionic acid mixture $(49,43$ and $8 \mathrm{~mol}$ acetic, propionic and butyric acids respectively $/ 100 \mathrm{~mol} ;(\triangle), 1.5 \times$ maintenance on a low-propionic acid mixture. Values are means and standard deviations (represented by vertical bars) for three determinations. For details of animals and procedures, see pp. 390-391.

daily at six increments of casein-N from 0 to $2500 \mathrm{mg} \mathrm{N} /$ $\mathrm{kg} \mathrm{W}^{0.75}$ daily the response in $\mathrm{N}$ balance was almost linear. At $300 \mathrm{~kJ} / \mathrm{kg} \mathrm{W}^{0.75}$ daily, glucose precursor supply amounted to $7 \cdot 17 \mathrm{~g} / \mathrm{kg} \mathrm{W}^{0.75}$ daily. Subsequent work by Chowdhury et al. $(1997 b)$, using sheep infused with $91 \mathrm{~kJ} / \mathrm{kg} \mathrm{W}^{0.75}$ as glucogenic VFA (16, 79 and 5 mol acetic, propionic, butyric acids/ $100 \mathrm{~mol}$ respectively) equivalent to $1.6 \mathrm{~g}$ glucose $/ \mathrm{kg} \mathrm{W}^{0.75}$, showed a reduction in BHB to $1.4 \mathrm{mmol} / \mathrm{l}$. Given that in the experiments reported here an infusion of glucose as precursor at $5.5 \mathrm{~g} / \mathrm{kg} \mathrm{W}^{0.75}$ was required to reduce BHB to $1.5 \mathrm{mmol} / \mathrm{l}$, it is reasonable to suggest that glucose requirements may be greater in cattle than in sheep, although more direct comparisons are needed to substantiate this contention.

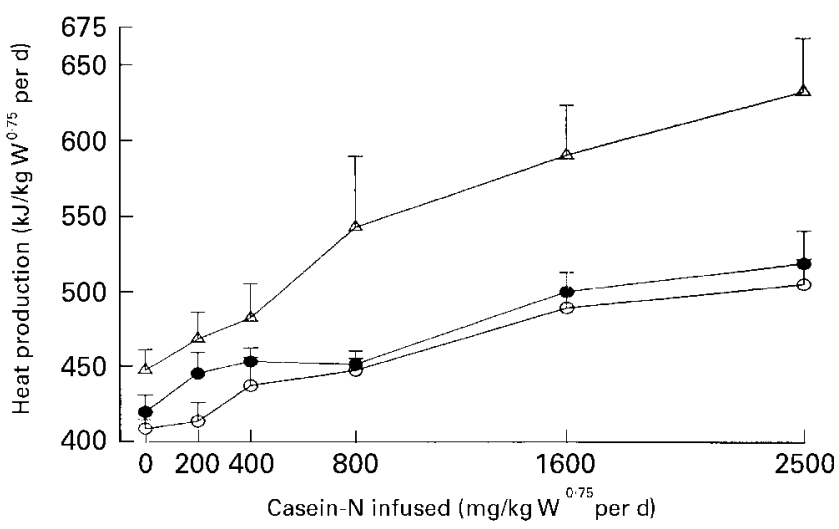

Fig. 2. Expt 2. Effect of infusion of different energy levels and type of volatile fatty acids in steers on changes in heat production with incremental infusion of casein $(0,200,400,800,1600$ and $2500 \mathrm{mg} / \mathrm{kg}$ metabolic body weight $\left.\left(\mathrm{W}^{0.75}\right)\right)$. (O), Maintenance $\left(450 \mathrm{~kJ} / \mathrm{kg} \mathrm{W}^{0.75}\right.$; Ørskov et al. 1977) on low-propionic acid mixture (65, 27 and $8 \mathrm{~mol}$ acetic, propionic and butyric acids respectively/ $100 \mathrm{~mol}) ;(\bullet)$, maintenance on a high-propionic acid mixture (49, 43 and $8 \mathrm{~mol}$ acetic, propionic and butyric acids respectively/100 mol); $(\triangle), 1.5 \times$ maintenance on a low-propionic acid mixture. Values are means and standard deviations (respresented by vertical bars) for three determinations. For details of animals and procedures, see pp. 390-391.
A recent comparison between fasted sheep, cattle and camels (Camelus dromedarius) showed that cattle had higher plasma levels of BHB than sheep, while in camels there was no increase in BHB during fasting ( $\mathrm{J}$ Wensvoort, DJ Kyle, ER Ørskov and DA Bourke, unpublished results).

\section{Relationship between glucose supply, plasma $\beta$-hydroxybutyrate and glucose, and urinary nitrogen excretion}

The high fasting daily urinary $\mathrm{N}$ excretion observed during the first experiment $\left(529 \mathrm{mg} \mathrm{N} / \mathrm{kg} \mathrm{W}^{0.75}\right)$ is similar to the values of $518 \mathrm{mg} \mathrm{N} / \mathrm{kg} \mathrm{W}^{0.75}$ obtained by Liu et al. (1997), $510 \mathrm{mg} \mathrm{N} /$ $\mathrm{kg} \mathrm{W}^{0.75}$ reported by Lobley et al. (1987), but lower than that reported by Ørskov et al. (1983; $\left.641 \mathrm{mg} \mathrm{N} / \mathrm{kg} \mathrm{W}^{0.75}\right)$. The difference between the values reported here and those of other workers is probably due to age differences. Ku Vera (1989) showed that daily fasting urinary $\mathrm{N}$ excretion was higher in young immature steers $\left(727 \mathrm{mg} \mathrm{N} / \mathrm{kg} \mathrm{W}^{0.75}\right)$ compared with mature fat steers $\left(539 \mathrm{mg} \mathrm{N} / \mathrm{kg} \mathrm{W}^{0.75}\right)$. Chowdhury et al. (1997b) observed a lower fasting $\mathrm{N}$ excretion with adult castrate sheep than young sheep.

The fact that incremental levels of glucose infusion $(1 \cdot 5$, $2 \cdot 5,3 \cdot 5,4 \cdot 5,5 \cdot 5$ and $6 \cdot 5 \mathrm{~g} / \mathrm{kg} \mathrm{W}^{0 \cdot 75}$ ) resulted in proportional reductions in urinary $\mathrm{N}$ excretion by $0.06,0.31,0.38,0.43$, 0.50 and $0.49 \mathrm{mg} \mathrm{N} / \mathrm{d}$ respectively demonstrates the $\mathrm{N}$ sparing effect of glucose on body protein catabolism. Corresponding reductions in plasma BHB with successive glucose infusions were $0.29,0.47,0.51,0.52,0.60$ and $0.60 \mathrm{mmol} / \mathrm{l}$. These results followed closely those of nonesterified fatty acids and urinary $\mathrm{N}$, and were inversely related to trends in plasma glucose, demonstrating clearly the anti-ketogenic effects of exogenous glucose in the fasted state (Ku Vera, 1985, 1989; Chowdhury et al. 1997a). The absence of any further reduction in $\mathrm{N}$ excretion when glucose infusion was raised to $6.5 \mathrm{~g} / \mathrm{kg} \mathrm{W}^{0.75}$ suggests a limit to the $\mathrm{N}$-sparing effect. This is supported by the absence of any further reduction in BHB at the highest infusion level, and is in agreement with the finding of $\mathrm{Ku}$ Vera (1989) that large amounts of glucose (above $400 \mathrm{~g} / \mathrm{d}$ ) failed to reduce $\mathrm{N}$ excretion any further. This finding supports the observation that there is a minimum protein turnover even during periods of total food deprivation (Lobley et al. 1987).

\section{Efficiency of utilization of volatile fatty acids}

While our work was not designed to study utilization of VFA, the efficiency when calculated as the increment in heat production as a result of increasing VFA infusion from 1.0 to $1.5 \times$ maintenance was 0.64 , which is very similar to values from much more extensive work reported with sheep (Ørskov et al. 1979) and with cattle (Ørskov \& MacLeod, 1993).

\section{Practical implications}

The apparent absence of any clear response of $\mathrm{N}$ retention to energy supply suggests that the earlier model proposed by Balch (1967) was affected by a glucose deficiency. He suggested that at any given $\mathrm{N}$ intake, $\mathrm{N}$ retention is a function of both $\mathrm{N}$ intake and exogenous energy intake, 
and that, irrespective of $\mathrm{N}$ intake, $\mathrm{N}$ retention would always be negative when energy supply is low. Earlier work by $\mathrm{Ku}$ Vera (1989), Meehan (1994) and Chowdhury et al. (1997b), showed that not only can a positive $\mathrm{N}$ balance be achieved when in negative energy balance $\left(159 \mathrm{~kJ} / \mathrm{kg} \mathrm{W}^{0.75}\right)$, but that substantial increases in tissue gain can occur when in negative energy balance fuelled by endogenous energy, provided glucose requirements are met. Within the limits imposed in these experiments, no further $\mathrm{N}$-sparing effect seems apparent when glucose supply is increased above that required to reduce to BHB to basal levels.

Marston (1948), quoted by Webster et al. (1974), showed that fasting heat production depended on the level of nutrition before fasting. We have identified, in agreement with Chowdhury \& Ørskov (1994), yet another reason why fasting metabolism is an inappropriate basis for measuring the utilization of nutritionally-balanced diets for ruminants, and that such measurements should be based at a level of glucose supply equivalent to approximately $5.5 \mathrm{~g} / \mathrm{kg} \mathrm{W}^{0.75}$ or more daily when plasma BHB is normal. The data reported here, compared with those for sheep (Chowdhury et al. 1997b), suggest that there is a species difference between cattle and sheep in glucose requirement and glucose metabolism. Fasting $\mathrm{N}$ excretion was consistently higher in cattle than sheep, and for a given input in glucogenic VFA infusion, cattle seem to respond more than sheep. However, differences in age, weight, maturity and physiological state will confound cross-species comparisons. Further research is needed to substantiate these findings.

\section{References}

Balch CC (1967) Problems in predicting the role of non-protein nitrogen as a substitute for protein in rations for farm ruminants. World Review of Animal Production 3, 84-91.

Chowdhury SA \& Ørskov ER (1994) Implications of fasting on the energy metabolism and feed evaluation in ruminants. Journal of Animal and Feed Science 3, 161-169.

Chowdhury SA, Ørskov ER, Hovell FDDeB, Scaife JR \& Mollison G (1997a) Protein utilization during energy undernutrition in sheep sustained by intragastric infusion: effects of protein infusion level, with or without sub-maintenance amounts of energy from volatile fatty acids, on energy and protein metabolism. British Journal of Nutrition 77, 565-576.

Chowdhury SA, Ørskov ER, Hovell FDDeB, Scaife JR \& Mollison G (1997b) Protein utilization during energy undernutrition in sheep sustained by intragastric infusion. Effect of body fatness on the protein metabolism of energy-restricted sheep. British Journal of Nutrition 78, 273-282.

Davidson J, Mathieson J \& Boyne A (1970) The use of automation in determining nitrogen in Kjeldahl method. Analyst 95, 181-193.

Fattet I, Hovell FDDeB, Ørskov ER, Kyle DFJ, Pennie K \& Smart $\mathrm{R}$ (1984) Undernutrition in sheep: the effect of supplementation with protein on protein accretion. British Journal of Nutrition 52, 561-574.

Hovell FDDeB, Ørskov ER, Kyle DJ \& MacLeod NA (1983) Basal urinary $\mathrm{N}$ excretion and growth response to supplemental protein by lambs close to energy equilibrium. British Journal of Nutrition 50, 173-187.

Ku Vera J (1985) Mechanisms of the nitrogen sparing effect of glucose. MSc Thesis, University of Aberdeen.
$\mathrm{Ku}$ Vera J (1989) Energy and protein metabolism in cattle nourished by intragastric infusion of nutrients. $\mathrm{PhD}$ Thesis, University of Aberdeen.

$\mathrm{Ku}$ Vera J, MacLeod NA \& Ørskov ER (1990) Construction and operation of an open-circuit ventilated hood system for cattle nourished wholly by intragastric infusion of nutrients. Animal Feed Science and Technology 28, 109-114.

Liu SM, MacLeod NA, Luo QJ, Kyle DJ, Nicol P, Harbron CF \& Ørskov ER (1997) The effects of acute and chronic protein depletion and accretion on plasma concentrations of insulin-like growth factor-1, fibronectin and total protein for ruminants nourished by intragastric infusion of nutrients. British Journal of Nutrition 78, 411-426.

Lobley GE, Connell A \& Buchan V (1987) Effect of food intake on energy and protein metabolism in finishing beef steers. British Journal of Nutrition 57, 457-465.

MacLeod NA, Corrigal W, Stirton R \& Ørskov ER (1982) Intragastric infusion of nutrients in cattle. British Journal of Nutrition 47, 547-552.

Marsh WH, Fingerhut B \& Muller M (1965) Automated and manual methods for determination of blood area. Clinical Chemistry 11, 624-627.

Marston HR (1948) Energy transaction in the sheep. Australian Journal of Science and Research 1B, 93-112.

Matsubara C, Nishikawa Y, Yoshida Y \& Takamura K (1983) A spectrophotometric method for the determination of free fatty acid in serum using acyl-coenzyme A synthetase and acylcoenzyme A oxidase. Analytical Biochemistry 130, 128-133.

Meehan DJ (1994) Effect of glucogenic precursors in VFA on protein energy interrelations in cattle. MSc Thesis, University of Aberdeen.

Ørskov ER, Grubb DA, Smith JS, Webster AJF \& Corrigal W (1979a) Efficiency of utilization of volatile fatty acids for maintenance and energy retention by sheep. British Journal of Nutrition 41, 541-551.

Ørskov ER, Grubb DA, Wenham G \& Corrigal W (1979b) The sustenance of growing and fattening ruminants by intragastric infusion of volatile fatty acids and protein. British Journal of Nutrition 41, 553-558.

Ørskov ER \& MacLeod NA (1982) The determination of the minimal nitrogen excretion in steers and dairy cows and its physiological and practical implications. British Journal of Nutrition 47, 625-636.

Ørskov ER \& MacLeod NA (1993) Effect of different levels of energy input of different proportions of volatile fatty acids on energy utilization in growing ruminants. British Journal of Nutrition 70, 679-687.

Ørskov ER, MacLeod NA, Fahmy STM, Istasse LA \& Hovell FDDeB (1983) Investigation of nitrogen balance in dairy cows and steers nourished by intragastric infusion. Effect of submaintenance energy input with or without protein. British Journal of Nutrition 50, 99-107.

Trinder P (1969) Determination of glucose using an alternative oxygen acceptor. Annals of Clinical Biochemistry 6, 24-27.

Webster AJF, Brockway JM \& Smith JS (1974) Prediction of the energy requirement for growth in beef cattle. 1. The irrelevance of fasting metabolism. Animal Production 19, 127-139.

Weekes TEC (1989) Hormonal control of glucose metabolism. In Physiological Aspects of Digestion and Metabolism in Ruminants, pp. 183-200 [T Tsuda, Y Sasaki and R Kawashima, editors]. New York and London: Academic Press.

Zavin J \& Snarr J (1973) An automated method for the use of measurement of 3-hydroxybutrate. Analytical Biochemistry 52, 456-461. 